\title{
Running over the Stage: Webster and the Running Footman
}

Although the frequent stage direction 'passing over the stage' has provoked much discussion as to its precise meaning, 'running over the stage' has attracted much less attention. Indeed, the famous Elizabethan theatrical clown Will Kemp achieved more fame by morris dancing than by running, though in his case heightened by being from London to Norwich. ${ }^{2}$ In early modern English drama there are, nevertheless, many kinds of running called for in stage directions. Alan Dessen and Leslie Thomson's Dictionary of Stage Directions in English Drama, 1580-1642 lists roughly 260 examples under the headwords 'running', 'hastily, in haste', and others, divided into four categories. ${ }^{3}$

1. 'enter/exit running/in haste'; this is the largest group, and includes examples such as 'Enter in haste ... a footman' (Middleton, A Mad World My Masters 2.1.6.2-6.3), 'Enter Bullithrumble, the shepherd, running in haste' (? Greene, Selimus sc. 10; line 1877), 'Enter Segasto running, and Amadine after him, being pursued with a bear' (Anon., Mucedorus B1r), and presumably 'Enter Juliet somewhat fast, and embraceth Romeo' (Shakespeare, Romeo and Juliet 2.5.15.1).

2. 'runs in/away/out/off'; a typical example is 'Lion roars. Thisbe ... runs off' (Shakespeare, A Midsummer Night's Dream 5.1.253.1).

3. 'runs at someone or is run through with a sword'; examples include 'He draws his rapier, offers to run at Piero; but Maria holds his arm and stays him' (Marston, Antonio's Revenge 1.2 [Q 1.4].375-6), and 'Flamineo runs Marcello through' (Webster, The White Devil 5.2.14).

4. runs overlabout the stage'; examples include 'After an alarum, and people running over the stage, enter Osmond, a Tartar, with his sword bloody' (Carlell, Osmond the Great Turk A2r) and 'Some beggars run over the stage' (Brome, A Jovial Crew 4.2; p 431). ${ }^{4}$ 
Leaving aside running people through, it is clear that running was a standard and frequent activity on stage; what is less clear is that an important and consistent set of conventions and expectations seems to have surrounded the acting of running and haste, especially in the representation of running footmen (see the first example above). Questions of casting, costume, language, physical activity, and acting are all involved, as well as the related question of how the playwrights' instruction in haste was conveyed to an audience.

These codes can usefully be explored by using the dramatist John Webster's densely punning prose 'character' of 'A Footman' as a guide to both the imaginative and stage representation of running footmen in the early seventeenth century.

\section{'A Footman' by John Webster}

Let him be never so well made, yet his legs are not matches, for he is still setting the best foot forward. He will never be a staid man, for he has had a running head of his own ever since his childhood. His mother (which out of question was a light-heeled wench) knew it, yet let him run his race, thinking age would reclaim him from his wild courses. He is very long-winded, and without doubt, but that he hates naturally to serve on horseback, he had proved an excellent trumpet. He has one happiness above all the rest of the serving men, for when he most overreaches his master he's best thought of. He lives more by his own heat than the warmth of clothes; and the waiting woman hath the greatest fancy to him when he is in his close trousers. Guards he wears none, which makes him live more upright than any cross-gartered gentleman usher. 'Tis impossible to draw his picture to the life, 'cause a man must take it as he's running. Only this: horses are usually let blood on St Stephen's Day; on St Patrick's Day he takes rest, and is drenched for all the year after. ${ }^{5}$

In the rest of this essay I shall use excerpts from this 'character' as headings for each section.

\section{'Let him be never so well made, yet his legs are not matches, for he is still setting the best foot forward. He will never be a staid man, for he has had a running head of his own ever since his childhood.'}

Webster's opening may confuse a modern reader who thinks of a footman as a flunkey in a powdered wig serving at table in a grand house in another 
century, but a seventeenth-century reader would not have needed the Oxford English Dictionary definition: '(3) An attendant or foot-servant. In early use, a runner in attendance upon a rider of rank; and, later, a servant who ran before his master's carriage, called more fully a running-footman'. A footman was so called because he was not a horseman; his job was to run on his own feet, either in attendance on his master or as a bearer of messages. Hence Webster's jest about the footman's legs never making a symmetrical match, because the footman is always running. Thus he can be neither 'staid, of grave deportment' nor 'stayed, detained in one place'. That running is the essence of a footman's character is reinforced by the play on 'running head' as both 'inclination to run' and 'of flighty wits'. Webster is simply playing with what everyone knew: that footman $=$ runner. $^{6}$

This knowledge helps us understand the likely mode of entry in the stage direction from A Mad World My Masters quoted above: 'Enter in haste [one of Follywit's comrades dressed as] a footman'. Sir Bounteous, to whom the supposed footman has entered, reacts jestingly: 'How now, linen stockings and three score miles a day: whose footman art thou?' (2.1.8-9). The demands of the job are also clear to Titus, in Shakespeare's Titus Andronicus, when he says to Tamora, 'I will dismount, and by thy wagon wheel / Trot like a servile footman all day long' (5.2.54-5). Massinger, in The Maid of Honour, has a messenger urged to 'haste unto the Court'. The willing reply is 'I will out-run / A footman for your pleasure' (5.1.54-5). Footmen were runners by occupation, and fast.

In the anonymous play Look about You we get a sense of how the constant running of a footman might be turned to comic advantage on stage. The Duke of Gloucester has asked that 'some nimble-footed fellow' be sent to him to carry a message to his sister. Redcap, the man chosen, is 'swift and trusty', but has a bad stammer:

Redcap I I am am Re Redcap s s sir.

Gloucester Run, Redcap, to Stepney.

Redcap I'll be at Stepney p p presently.

Gloucester Nay, stay, go to the Lady Falconbridge, my sister.

Redcap The La La Lady Fau Fau Faukenbreech, I r r run sir.

Gloucester But take thy errand, tell her I am prisoner,

Committed to the Fleet.

Redcap I am g g glad of th th that, my fa fa father the p p porter sha shall ge ge get a $f f$ fee by you.

Still runs. 
Gloucester Stand still awhile. Desire her to make means

Unto Prince Richard for my liberty.

At thy return (make speed) I will reward thee.

Redcap I am g g gone si sir.

[Exit running.]

(11. 387-405)

In addition to the verbal low comedy of the stammer, this episode seems to depend for its humour on the old gag of a servant so anxious to obey that he tries to leave before he knows his errand fully. Here, the gag is heightened by the physical energy of the running footman constantly racing off at high speed and having to be called back no fewer than three times before finally getting off stage at the fourth attempt, running. The stage direction 'Still runs' is even more intriguing, coupled with Gloucester's plea 'Stand still awhile', since together they raise the possibility that Redcap is running on the spot, or around the Duke, even while he gets instructions.

\section{'His mother (which out of question was a light-heeled wench) knew it, yet let him run his race, thinking age would reclaim him from his wild courses.'}

The implication that the footman's mother was sexually promiscuous ('lightheeled') sows a seed that will be picked up by Webster later in the piece, but its immediate function is to certify her son's good high-stepping lineage to 'run his race'. Not only will he 'pursue his course of life', but also Webster makes it punningly explicit that footmen's running was put to sporting as well as occupational use. ${ }^{7}$ This pun and the sexual innuendo earlier get further emphasis from 'courses' as meaning both 'races' and 'reprehensible (sexual) behaviour' - sowing his wild oats.

Many references to footmen racing appear in the drama, especially as occasions for their masters to wager on them. In Rowley, Middleton, and Heywood's An/The Old Law a master pondering whether he most needs a butler, a bailiff, a cook, a coachman, or a footman, suggests to the footman that 'you can win me wagers, / Footman, in running races', to which the footman replies, 'I dare boast it, sir' (2.1.257-8). Although many plays refer to racing, such as 'Antony [stripped] for the course' in Julius Caesar (1.2.0.10.2), Shirley's Hyde Park seems to be the only play from the period to actually stage a race. That foot-races at Hyde Park were becoming a regular London attraction by the 1630s is confirmed by Brome's A Jovial Crew, during which 
a gentlemen invites the ladies to 'make a fling to London' so as to visit, among other pleasurable resorts, 'Hyde Park to see the races, horse and foot' (act 2; p 372).

In Shirley's Hyde Park the wagering and the odds on the two men competing in the foot-race are slyly paralleled with a competition by the gentlemen to seduce various ladies. 'Will you venture anything, lady?' (3.1; p 494) is a loaded question indeed. But the real betting on the two competitors seems to be linked to the gentlemen actually following them around the course, presumably so as to see all the action, or just possibly because the main event between the two foot men also includes a gentleman's race: 'I run with the company'(494), says one gentleman. Another is observed by one of the ladies, who asks, 'Is that well-trussed gentlemen one of them that run?' (497). When Lord Bonvile says 'I must among the gamesters' (495), he is employing a multiple pun on 'gamesters' as (1) runners, (2) gamblers, (3) frolicsome people, and (4) amorous or lewd people.

The race, furthermore, actually appears on stage. One of the ladies enquires 'Will they run this way?' and is told 'Just before you' (499). A moment later the noise of all the followers signals that the race has begun, and a stage direction reads 'The two runners cross the stage, followed by Lord Bonvile, Venture, and others' (499). They remain on stage while six lines are spoken before their 'exeunt', and reappear similarly about twenty lines later. The wording of the stage direction makes a clear distinction between the 'runners' (that is, the two racing footmen) and the gentlemen who are betting on them, shouting lustily, and following their course. Just how this would have been staged is tantalizingly unclear, especially whether there might have been any stylization (such as a deliberately slow motion representation of fast running, or running on the spot), or whether the cries from the spectators to 'make way, for shame' $(499,500)$ may reveal a deliberate stage obstruction of the runners so as to keep them in view longer. Possibly, in practice, the runners simply went as fast as they could, perhaps entering at one door and making a complete circuit to the front and across the stage before crossing back to the tiring house and exiting by the opposite door. Dialogue may have had to follow their departing backs. What is clear, however, is that all the spectators (except some of the ladies who, conveniently for us, need things explained to them) are assumed to be fully conversant with the way both foot-races and horse-races were run, and how to wager large sums on them.

Finally, just as gentlemen knew the odds on the runners, footmen themselves are shown to be canny competitors. In Webster's Appius and Virginia 
Appius has 'heard of cunning footmen that have worn / Shoes made of lead some ten days 'fore a race / To give them nimble and more active feet' (1.1.48-50). He goes on to suggest that politicians who 'aspire to eminent place' should learn the lesson, and 'Load themselves with excuse and faint denial, / That they with more speed may perform the trial'. Similarly, in Field, Fletcher, and Massinger's The Honest Man's Fortune a lawyer is described as adopting running tactics in order to dupe the opposing side:

The people in the favour of your side

$$
\text { ... began to laugh }
$$

Your adversary's advocate to scorn;

Who, like a cunning footman, set me forth

With such a temperate easy kind of course

To put him into exercise of strength,

And followed his advantages so close

That when your hot-mouthed pleader thought he'd won,

Before he reached it he was out of breath,

And then the other stripped him.

Any distance runner with good stamina or a late kick will be familiar with the tactic of starting a race slowly so as to lull opponents into committing themselves too soon. ${ }^{8}$ What is pertinent to the dramaturgy here is the playwrights' expectation that such an extended simile would be readily comprehensible to the playhouse audience (for whom, after all, foot racing was just one of the entertainments on offer to gentlemen in London, along with horse racing, bear baiting, cock fighting, gambling, brothels, and plays themselves).

\section{'He is very long-winded, and without doubt, but that he hates naturally to serve on horseback, he had proved an excellent trumpet.'}

Webster's comment that his footman 'hates naturally to serve on horseback' is a reminder that footmen usually accompanied on foot a rider or a horsedrawn carriage: Absalon in Peele's play David and Bathsheba boasts that 'Fifty fair footmen by my chariot run' (1. 1215). But in Fletcher's The Noble Gentleman Jacques observes that 'One cart will serve for all your furniture, / With room enough behind to ease the footman' (5.1.106-7). Running footmen were, it seems, understandably willing to hitch a ride if offered one.

More important than the horse reference is Webster's play on 'longwinded', where here the primary meaning is 'long-breathed, capable of not 
running out of breath'. While an obvious virtue for a mounted trumpeter, for a footman (and for the actor playing him) stamina and good lungs are crucial. In The City Madam Massinger has a character explain why he has been away so long: 'you may consider, / Being forced to fetch these from the Old Exchange, / These from the Tower, and these from Westminster, / I could not come much sooner'. Another character comments, 'Here was a walk / To breathe a footman' (1.1.127-31); in other words, going from the centre of London to the Tower at its eastern boundary, and then beyond London in the west all the way to Westminster, and then back again, would be a long enough journey to give even a footman a good workout.

When the comic servant Dromio of Syracuse in Shakespeare's Comedy of Errors enters to obtain from his master's wife Adriana a purse of money to bail her husband from prison, Dromio might be acting being out of breath and exhausted even more than the lines imply:

\section{Enter Dromio [of] Syracuse running.}

Dromio Here, go - the desk, the purse! Sweet now, make haste!

Luciana How? Hast thou lost thy breath?

Dromio

By running fast.

The stage direction specifies the entry as 'running', the message is disjointed and barely comprehensible, and Luciana's comment confirms that he is out of breath and has had to gasp his message out. He stupidly or deliberately misunderstands her 'How?' (= 'What's this!') as 'How ...' (= 'What was the cause, in what manner') so as to answer in a way that makes her question sound stupid.?

The passage from Middleton's A Mad World My Masters quoted earlier about Sir Bounteous addressing a footman as 'three-score mile a day, whose footman art thou?' continues with the footman, who entered 'in haste', replying: 'Pray, can your worship tell me, [panting] hoh, hoh, hoh, if my lord be come in yet?' (2.1.6.2-11). I agree with the modern editorial stage direction here: the 'hoh, hoh, hoh' seems to be in effect a stage direction for the footman to pant or gasp, as in The Comedy of Errors, just as 'ha, ha, ha' when printed in a play is a cue to an actor to laugh rather than to pronounce the syllables exactly. And the comic possibility, noted above in Look About You, for a servant to try to run off before he has been fully briefed occurs here no fewer than five times, along with two utterances of 'puh' (= 'pew') by Sir 
Bounteous, reacting to the 'lousy seven mile an hour' footman's strong smell of sweat $(2.1 .26,42,36)$.

This evidence and that adduced above usefully document what logic would suggest: that the direction for an actor to 'enter in haste' will normally mean 'enter running'. Only a young lady such as Juliet may retain rather more decorum by entering 'as fast as may be'. In addition, gasping or panting was clearly an available stage amplification of the effect of ' haste'. To this we can add the possible reaction of other characters to the 'sweaty footman' of Randolph's play The Jealous Lovers (2.6; p 100), confirmed by Sir Bounteous's 'puh' discussed above and the direction in Clavell's The Soddered Citizen: 'Enter ... Mountain hastily, in a sweat' (3.1.1121-2). A number of other plays require characters to 'enter sweating'. And an actor himself is far more likely to indicate sweat by mopping his brow than by elaborate makeup.

\section{'He has one happiness above all the rest of the serving men, for when he most overreaches his master he's best thought of.'}

Webster's footman, occupying the lowest level within the hierarchy of 'serving men', has at least the opportunity to 'overreach' his master legitimately, not in the sense of 'cheat' but in the sense of 'overtake, outrun', and thus earn his master's praise. Any other servants who 'overreach' their masters will be severely punished no doubt.

\section{'He lives more by his own heat than the warmth of clothes; and the waiting woman hath the greatest fancy to him when he is in his close trousers.'}

This one sentence of Webster's contains a complex and significant series of references. First, the 'heat' generated by physical exertion is as recognizable on stage to an observer as it would be in real life. In Middleton's Hengist, King of Kent; or The Mayor of Queenborough, a footman, already identified as such by his 'dusty pumps' (pumps being the light single-soled low shoes favoured by fencers, dancers, and runners), is greeted thus: 'And what's the news with thee, well-stewed footman?' (5.1.17-24). As he runs off on a further message, his hot and sweaty appearance causes further comment: 'That fellow will be roasted against supper, he's half enough already, his brows baste him' (5.1.34-5). 
The 'waiting woman' lurking in the second half of Webster's sentence, however, alerts us to an additional jesting sense of sexual heat, especially in conjunction with the tight-fitting ('close') trousers she admires, and the implied absence of other clothes. Footmen's clothing is constantly referred to as thin and wretched, demonstrating the wear and tear they get, and the footmen's traditional poverty (see Autolycus' complaint in Shakespeare's The Winter's Tale [4.3.48-63] about the 'rags' and 'detestable things' a footman has left him to wear). Furthermore, footmen and runners are often referred to as 'bare', as in this example from Sharpham's The Fleire: 'Tell me true, were you never ushers to some great man's coach-mares? Did you never run bare before them?' (2.485-7). 'Bare' at this time often means 'bare-headed', with the hat removed as a token of respect, but here must refer to clothing. It may mean as little as the reference in Field, Fletcher, and Massinger's The Honest Man's Fortune to Rumour: 'it runs ... like a footman without a cloak, to show that what's once rumoured, it cannot be hid' (2.2.222-3), or, in Chapman's The Gentleman Usher, 'he goes like / A prince's footman, in oldfashioned silks, / And most times in his hose and doublet only' (1.1.111-3). On the other hand, running 'bare' might suggest stripping down to a shirt, or stripped to the waist. Shakespeare's famous witty clown Robert Armin recounts a jest of King James's fat fool Jemmy Camber challenging the king's best footman to a race, and describes Jemmy as 'stripped into his shirt, trussed round for the purpose. ${ }^{10}$

On occasion, in fact, racers may have stripped altogether. At the end of the list of fashionable London entertainments quoted above from Brome's $A$ Jovial Crew, including 'races, horse and foot', the gentleman leeringly offers an opportunity to 'see the Adamites run naked afore the ladies' (act 2; $\mathrm{p}$ 372). Adamites were what we would now call naturists or nudists, but with a religious impulse: a sect that imitated the Edenic Adam in going unclothed. Apparent confirmation that London foot-races were sometimes raced naked appears in Shirley's Hyde Park, where Mistress Carol demands the right to 'see / Plays when I have a mind to't, and the races, / Though men should run Adamites before me'. A few minutes later, her mind still clearly on the subject, she asks, 'Cousin, do they run naked?' The exchange continues:

Mistress Bonavent That were a most immodest sight!

Mistress Carol Here have been such fellows, cousin.

Mistress Bonavent It would fright the women.

Mistress Carol Some are of opinion it brings us hither! 
There is little likelihood that the runners who appear on stage a moment later are entirely naked, since a total absence of clothing seems never to occur in performance at this period, but they are nonetheless likely to be stripped to some degree in a way that gives visual reinforcement to their profession and activity. Indeed, in Beaumont's The Knight of the Burning Pestle, high class hotel accommodation is commanded with these instructions: 'see / Our beds prepared, and bring us snowy sheets, /Where never footman stretched his buttered hams' (2.356-8). This suggests knowledge of footmen greasing their thighs, presumably for warmth. Alternatively, Armin recounts that Jemmy Camber, preparing for his race, 'as he had seen the king's footmen do, washed his feet with beer, and soaked them in butter. ${ }^{21}$ Either way, nobody wants beds or sheets slept in by a runner.

Nobody, that is, but Webster's amorous 'waiting woman', who has 'the greatest fancy' to the footman 'when he is in his close trousers'. Of more interest to a stage or sports historian than the waiting woman's fascination with the revealing tightness of the man's nether garments is the fact that 'trouses' (as Webster spells it, and which emphasizes that they are not loose trousers) were a garment especially associated with the Irish. Indeed, 'trouse' and 'trews' are Gaelic words originally. The $O E D$ quotes a 1630 jest that 'a jealous wife was like an Irish trouse, always close to a man's tail'. Technically trouses were close fitting breeches at the top, usually with stockings sewn on for the lower legs and feet.

There are dozens of references to Irish footmen in the drama of the period, including of course the Irishman racing the English footman in Hyde Park, who appears on stage to cheers of 'a Teague! a Teague!' (3.1; pp 499, 500). We must presume that the long hair of the low-class Irish kern, as well as either 'trouses' or bare legs, and on occasion the great Irish mantle, are likely to have been a standard stage costume. A character in Fletcher's The Coxcomb disguises himself 'like an Irish footman' in order to win access to his love, and tells the audience 'I hope I am wild enough for being known' (that is, 'not to be known'). That 'wild' means Irish in appearance is confirmed when he adds 'now for my language', which is clearly stage Irish: 'Now by my troth and faith' and various conventional Irish oaths. The character adds, once alone, 'this rebel tongue sticks in my teeth worse than a tough hen' (2.3.0.114). But clearly actors were used to cod Irish, as so many plays employ it, even Ben Jonson's Irish Masque at Court where four of the principal characters are footmen. 


\section{'Guards he wears none, which makes him live more upright than any cross-gartered gentleman usher.'}

In addition to all the references to ill-kempt and nearly naked Irish footmen, and to wretched clothing, we also find footmen wearing 'old-fashioned silks' (in The Gentleman Usher, referred to above), and 'old velvet trunks [trunkhose] / And his sliced Spanish jerkin' (in Fletcher's The Captain, 3.3.34-5), all out of fashion and old, perhaps because castoffs, or perhaps because their masters never bothered giving them another suit. The 'guards' that Webster refers to were ornamental bands on clothing, often velvet, and although this rich material was normally entitled to be worn only by the well-born and wealthy, an earlier Webster reference makes clear that bands or trimmings of velvet could be part of a footman's livery and hence a mark of servitude:

Malevole You are in good case since you came to court, fool. What, guarded! Guarded!

Passarello Yes, faith: even as footmen and bawds wear velvet, not for an ornament of honour, but for a badge of drudgery. ${ }^{12}$

Surprisingly, however, Webster's footman 'wears none', presumably for the sake of the comparison with the cross-gartered gentleman usher. Cross-gartering was also old-fashioned by the second decade of the seventeenth century, when Webster wrote his 'character', but perhaps he recalled Malvolio's complaint that cross-gartering (above and below the knee) 'does make some obstruction in the blood' (Twelfth Night 3.4.19-20). It is not clear whether Webster's footman is 'more upright' than a gentleman usher because more virtuous, or because more athletic and unencumbered with cross-garters, or perhaps, jestingly, both.

\section{'Tis impossible to draw his picture to the life, 'cause a man must take it as he's running.'}

This is an old joke: because he is always running, the footman's portrait cannot be drawn from life because he never stands still long enough.

Another more interesting joke seems to be embedded in the play Eastward Ho by Chapman, Jonson, and Marston starts thus:

Enter a Coachman in haste, in his frock, feeding.

Coachman Here's a stir when citizens ride out of town, indeed, as if all 
the house were afire! 'Slight, they will not give a man leave to eat's breakfast afore he rises.

Enter Hamlet, a footman, in haste.

Hamlet What, coachman! My lady's coach, for shame! Her ladyship's ready to come down.

[Exit Coachman.]

Enter Potkin, a tankard-bearer.

Potkin 'Sfoot, Hamlet, are you mad? Whither run you now? You should brush up my old mistress.

[Exit Hamlet.]

Editors have been quick to note that the line 'Hamlet, are you mad?' is almost certainly a jest at the recent success of Shakespeare's Hamlet, but have commented little on the running. As we have seen, 'in haste' almost certainly means 'running', so first the Coachman and then the footman Hamlet enter running. Hamlet's lines betray the agitation of his haste, just as the instant disappearance of the Coachman without speaking implies a running exit. Particularly notable is that Potkin (perhaps also entering in haste, to extend the sight gag) says to Hamlet 'Whither run you now?' We have no indication where he is running, but might speculate that either he is making to follow the Coachman, has run into the entering Potkin, or is simply running around the stage because that is what footmen do if not yet given a destination. Hamlet re-enters with his mistress a few minutes later, and when she calls for her coach and threatens to swoon Hamlet exits again, crying 'Coach, coach, my lady's coach!', and a few moments later reports back 'Your coach is coming, madam' $(3.2 .29,37)$. It is inconceivable that this exit and entry too are not at a full run. The physical humour of the scene is at least as important as the verbal quip about madness.

If 'are you mad?' refers to Shakespeare's play, why is the running footman in such haste? Is this a reference to Hamlet's 'Hide fox, and all after' (4.2. 27), his invitation to Rosencrantz and Guildenstern to catch him if they can, as he exits running as if playing fox and hounds? This seems the most likely explanation; and if so, Burbage's acting of the exit must have been memorable. A more general comment on very active performance by Burbage may be intended, perhaps based on erratic running about in 1.5 following the Ghost beneath the stage. ${ }^{13}$ Or might the running in Eastward Ho be a reverse joke? Was Burbage's melancholic Dane generally so slow that showing a running Hamlet was funny in itself? Or did Hamlet's pretended madness extend 
to Irish costume? Or is there some other possibility, now lost to us, deriving from the original production of Hamlet? Despite the impossibility of a firm answer, the implications of how the Eastward Ho footman Hamlet may in performance have related to running in Shakespeare's play Hamlet or Burbage's characterisation of Hamlet raises intriguing questions.

\section{'Only this: horses are usually let blood on St Stephen's Day; on St Patrick's Day he takes rest, and is drenched for all the year after.'}

Webster's summation confirms, if confirmation were needed after the reference to 'close trousers' earlier, that his typical footman is Irish. Whereas horses were traditionally bled and drenched (dosed) on 26 December, 'St Stephen's Day', 'St Patrick's Day' has always been associated with the patron saint of Ireland. The association of horse- and foot-races is continued, but more significant are the meanings of 'drenched' for the footman: the primary meaning, as for horses, is 'dosed with medicine', and here might possibly include sweating, but the most likely play is on drunkenness. In Webster's play The Devil's Law-Case, which was written only shortly after New Characters, a surgeon jokes about a murder being legitimate: 'Why, 'tis no more than should I go and choke an Irishman, that were three quarters drowned, with pouring usquebaugh in's throat' (3.2.138-40). 'Usquebaugh' is Irish for 'whiskey', and 'drowned' probably carries the connotation of 'drunk'. Here is an association still prevalent in stereotypes of Irishmen, and one that might even have added a further dimension to the identification of running footmen on stage.

\section{Conclusion}

What this investigation has revealed is a limited but powerfully consistent view of the footman. These images are carried into stage representation and demonstrate that the actors of messengers, footmen, and others in the plays who enter 'in haste' are almost certainly 'running', and likely to indicate that they are gaspingly out of breath, hot, and sweating. In comedies there may be a standard gag of running towards the exit too soon, or even of running on the spot or around the stage while awaiting instructions. Costume will be specialized to the extent of light running pumps, old and often very worn clothing, or sometimes, especially for a race, very little clothing at all. More 
often than not clothing, general appearance (especially hair), and language will probably be Irish, perhaps augmented on occasion with drunkenness.

While none of these individual elements was entirely unknown to us before, their conjunction allows us to recognize and to speculate with more authority about a much wider category of stage representation of running than has previously been apparent to historians of literature, of sport, and of the theatre.

\section{Notes}

I should like to thank the Faculty of Humanities and Social Sciences at Victoria University of Wellington for a research grant for this paper, David Lawrence for intelligent ferreting for relevant stage directions and contexts, and Professor David Norton for inspired advice.

1 See Leslie Thomson, 'Passing over the stage - Again', Lena Cowen Orlin and Miranda Johnson-Haddad (eds), Staging Shakespeare: Essays in Honor of Alan C. Dessen (Newark DE, 2007), 23-44. Thomson canvasses the debate since Allardyce Nicoll's whimsical but unfortunately influential supposition about actors mounting the stage from the yard of the playhouse, and has confirmed that the stage direction indicated an entry onto the stage and subsequent exit from it by the usual stage doors.

2 See Kemp's Nine Days' Wonder (1600), ed. Alexander Dyce (London, 1840).

3 Alan C. Dessen and Leslie Thomson (eds), A Dictionary of Stage Directions in English Drama, 1580-1642 (Cambridge, 1999), 111, 185. Words in bold are other main headings in the dictionary.

4 All quotations have been modernized and punctuation and format made consistent. All quotations from plays, unless otherwise noted, are taken from the following editions, and are given act, scene, and line numbers in the text, or page or signature references otherwise. A caution is needed about individual plays in which stage directions may vary from one early edition to another. The reliability of individual citations, however, is less important than the aggregate and consistency of examples quoted. Dramatic Works in the Beaumont and Fletcher Canon, gen. ed. Fredson Bowers, 10 vols (Cambridge, 1966-96); Richard Brome, Dramatic Works (London, 1873); Lodowick Carlell, Osmond the Great Turk (London, 1657); Plays of George Chapman: Comedies, gen. ed. Allan Holaday (Urbana IL, 1970); ? John Clavell and ? Shakerly Marmion, The Soddered Citizen, Malone Society Reprints (Oxford, 1935 [1936]); ? Robert Greene, The Tragical Reign of Selimus, Malone Society Reprints (Oxford, 1908); Ben Jonson, ed. C.H. Herford and Percy and Evelyn 
Simpson, 11 vols (Oxford, 1925-1952); (Anon.) Look About You, Malone Society Reprint (Oxford, 1913); John Marston, Antonio and Mellida and Antonio's Revenge, Malone Society Reprints (Oxford, 1921); Philip Massinger Plays and Poems, ed. Philip Edwards and Colin Gibson, 5 vols (Oxford, 1976); (Anon.) Mucedorus (London, 1611); Thomas Middleton, Collected Works, ed. Gary Taylor and John Lavagnino (Oxford, 2007); George Peele, The Love of King David and Fair Bethsabe, Malone Society Reprints (Oxford, 1912); Thomas Randolph, Poetical and Dramatic Works, ed. W. Carew Hazlitt, 2 vols (London, 1875); The Norton Shakespeare, gen. ed. Stephen Greenblatt (New York and London, 1997); Edward Sharpham, The Fleire, ed. Hunold Nibbe, Materialien zur Kunde des älteren Englischen Dramas (Louvain, 1912; repr. Vaduz, 1963); James Shirley, Dramatic Works and Poems, ed. William Gifford and Alexander Dyce, 6 vols (London, 1833); Works of John Webster, ed. David Gunby, David Carnegie, and (vol. 1) Antony Hammond, (vol. 2 and 3) MacDonald P. Jackson (Cambridge, 1995-2007).

5 'A Foote-man' in Webster's New Characters (1614-15), in Works of John Webster, 3.465. For discussion of Overbury's Characters, to which Webster's were an addition, and the nature of these witty and often satirical prose character sketches, see 440-51 of the same volume. I have here modernized spelling and punctuation.

6 A footman might also refer simply to a man walking, often at the time called a 'passenger', and Will Kemp draws on the punning possibilities when he describes the start of the final day of his dance to Norwich: 'The next morning I left Higham, not staying [stopping] till I came to Barford Bridge, five young men running all the way with me, for otherwise my pace was not for footmen' (Kemp, Nine Days' Wonder, 15). Kemp seems to be jesting that his dance pace was so fast that he could outstrip 'footmen' (actually walkers, jokingly running footmen).

7 On foot-racing as a regular pastime, see, eg, a royal licence from 1569 for public games including 'the shooting with the standard, the shooting with the broad arrow, the shooting at the twelve score prick [target], the shooting at the Turk [a human-shaped target], the leaping for men, the running for men, the wrestling, the throwing of the sledge, and the pitching of the bar' (cited by L.A. Govett, The King's Book of Sports [London, 1890], 24). See also Roger Robinson, Running in Literature (Halcottsville NY, 2003). Professor Robinson's delightful and informative book includes reference to running in the plays of Shakespeare and other Elizabethan and Jacobean dramatists (esp. 65-70), and a brief history of the running footman. It is also responsible for my decision to investigate running further, especially how the early modern theatre is likely to have staged running and races. 


\section{i36 David Carnegie}

8 Apparently Professor Robinson, a marathon runner as well as an author (see note 7), is known for his warning 'start fast, finish slow' and advice 'start slow and finish fast'.

9 Ibid.

10 Robert Armin, Fool Upon Fool, ed. H.F. Lippincott, A Shakespeare Jestbook, Robert Armin's Foole Upon Foole (1600) (Salzburg, 1973), 86.

11 Ibid, 85.

12 Webster's Addition 1 to Marston's The Malcontent, lines 7-10, quoted from Gunby et al., Works of John Webster.

13 I am grateful to Paul Yachnin for this suggestion. 